Original Article

\title{
APPLICATION OF ULTRASONIC OR MICROWAVE RADIATION TO DELAY CRYSTALLIZATION AND LIQUEFY SOLID HONEY
}

\author{
Ewelina Sidor ${ }^{*}$ \\ Monika Tomczyk \\ Małgorzata Dżugan \\ Department of Chemistry and Food Toxicology, University of Rzeszów, Poland \\ *corresponding author: ewelina.sidor.dokt@gmail.com \\ Received: 19 January 2021; accepted: 16 November 2021
}

\begin{abstract}
A bstract
Crystallization of honey is a natural process occurring during honey storage and forces beekeepers to practice the decrystallization process, which mainly concerns honey heating. The aim of this study was to examine the possible use of ultrasounds or microwave radiation to delay the crystallization of honey and to liquefy crystallized honeys while maintaining their biological activity. Lime, acacia and multifloral honeys obtained from a local apiary were used. Fresh honeys were pretreated through ultrasounds $(40 \mathrm{kHz}$, for 5 and $20 \mathrm{~min}$ ) or microwaves ( $800 \mathrm{~W}, 4 \times 30 \mathrm{~s}$ ) in order to obtain samples U5, U20 and $M$, respectively. Experimental and control samples were stored for twelve months at room temperature $\left(20 \pm 2^{\circ} \mathrm{C}\right)$ without light. Crystallized honey was liquefied through the same methods of ultrasounds (sample U5* and U20*) and microwaves (sample $M^{\star}$ ). Naturally crystallized honeys were used as the controls. For fixed (U5, U20 and $M)$ and decrystallized (U5*, U20*, $\left.M^{\star}\right)$ honeys, the water content (refractometrically), antioxidant properties (DPPH method), total phenolics content (Folin-Ciocalteu method) and enzymatic activity (diastase, $\alpha$-glucosidase, $\beta$-galactosidase and $\alpha$-mannosidase) were determined. The analyzed physicochemical parameters for both fixed and liquefied honeys did not differ significantly ( $P>0.05$ ) in comparison to the control honey. Moreover, the decrystallization process increased the antioxidant activity of all tested honeys. The smallest changes in honey properties to ultrasonic treatments were observed, and this method was recommended to delay the crystallization process and significantly accelerate the liquefaction time of solid honeys without compromising its quality.
\end{abstract}

Key words: antioxidant activity, bee honey, decrystallization, ultrasounds

\section{INTRODUCTION}

Honey is a natural sweet food product produced by bees (Apis mellifera), which contains mainly simple sugars and water, but also organic acids, amino acids, vitamins, enzymes, bioelements, antioxidants and phenolic compounds (Sohaimy et al., 2015). Their content fluctuates significantly, mainly depending on the type and species of plants from which bees collect nectar or honeydew (Borkowska et al., 2011). To this date, over three-hundred ingredients belonging to several chemical groups have been discovered in honey, but most occur in trace amounts (Abeshu \& Bekesho, 2016).

Honey crystallization is a natural phenomenon occurring in natural unadulterated honey
(Stasiak \& Dolatowski, 2007). It is a physical process and therefore does not change the healing and nutritional properties of honey (Bakier \& Pękala, 2007). From a physical point of view, crystallization is the separation of glucose crystals from its supersaturated solution (Thrasyvoulouet al., 1994). Nectar honeys crystallize faster than honeydew honey, due to the low glucose and the high melecytose and fructose content honeydew honey crystallize very slowly (Rybak- Chmielewska et al., 2013).

Decrystallization, reverse to the crystallization process, involves the liquefaction of honey from a solid (crust) to a liquid phase (Subramanian et al., 2017). The process is most often carried out in a water bath at a temperature no higher than $40^{\circ} \mathrm{C}$, for $24-48$ hours. However, keeping honey 
for several days at $42^{\circ} \mathrm{C}$ can cause changes as strong as short-term heating (Kowalski et al., 2012). All honey types behave similarly when heated, which causes the loss of the crystalline phase. Despite the carried-out treatments, honey crystals often remain invisible resulting in re-crystallization. Improper decrystallization results in honey overheating and quality decrease (Bhandari et al., 2009). The main symptoms of honey overheating are a decrease in diastase number and an increase in 5-hydroxymethylfurfural (HMF or 5-HMF) content (Dżugan et al., 2018). HMF is the basic product of the transformation of simple sugars through dehydration in acid environment or during the Maillard reaction. HMF is not present or occurs in trace amounts in freshly collected honey. Its content increases when honey is overheated and thus it is recognized as a marker of the correct storage and distribution of honey. HMF has a negative effect on the human body, including neurotoxic, carcinogenic, genotoxic and mutagenic (Shapla et al., 2018). The European Union has set concentration limits of this substance in honey up to $40 \mathrm{mg} / \mathrm{kg}$, which requires effective methods for liquefying honey without changing its quality. The relatively new use of ultrasound accelerates the decrystallization and delays the re-crystallization of honey, as well as delays the crystallization of fresh honey (P. 420598). The two side effects of honey sonication are the disintegration of such microorganisms present in honey as yeast and spore-forming bacteria, especially of the genus Bacillus, which allows pasteurization to be avoided when honey is intended for export (Bogdanov, 2011). Recently, it has been proposed to use physical methods for decrystallization and to slow down the crystallization of fresh honey (Dżugan et al., 2017, P. 420598). The purpose of this work was to evaluate how the use ultrasonic or microwave radiation affects liquid fresh honey fixation as well as how solid honey liquefying affects its antioxidant and enzymatic activity.

\section{MATERIAL AND METHODS}

The three varietal honeys: acacia, multifloral and lime were collected in July 2016 from a local apiary. After centrifugation from the comb, fresh honey was divided into four equal parts (by volume $150 \mathrm{ml}$ each), three experimental and one control. The same was done for each type of honey.

\section{$1^{\text {st }}$ treatment: fixation of fresh liquid honey}

Two samples of honey were subjected to ultrasonic fixation $(U)(40 \mathrm{kHz}$, max honey temperature $43-45^{\circ} \mathrm{C}$ ) for 5 or 20 min (samples U5 and U20) with the use of an ultrasonic water bath (Polsonic Sonic-10, Poland). The next sample (M) was fixed with a microwave (800W, 4 cycles for $30 \mathrm{~s}$, with 2 min intervals for samples shaking and cooling, max honey temperature $73^{\circ} \mathrm{C}$ ). The fixed samples and control honey were stored at room temperature $\left(20 \pm 2^{\circ} \mathrm{C}\right)$ in the dark for twelve months. After this period, the quality of crystallized honeys was assessed in the same way as for fresh honey.

$2^{\text {nd }}$ treatment: liquefaction of crystallized honey Subsequently, the experimental samples were processed to complete liquefaction with the same methods: U5* $(40 \mathrm{kHz}, 5$ cycles for 5 min, max honey temperature $50^{\circ} \mathrm{C}$ regardless of the variety), U20* (40 kHz, for all tested honeys max temperature $\left.53^{\circ} \mathrm{C}\right) ; \mathrm{M}^{*}(800 \mathrm{~W}$, for multifloral and lime honey four cycles for $30 \mathrm{~s}$, with 2 min intervals for samples shaking and cooling, max honey temperature $80^{\circ} \mathrm{C}$, and for acacia honey 2 cycles for $30 \mathrm{~s}$, with intervals for samples shaking and cooling, max honey temperature $60^{\circ} \mathrm{C}$ ). After liquefaction, samples were evaluated regarding chosen parameters in relation to the control (naturally crystallized and not liquefied honey).

The visual assessment of the samples included determination of the color, crystallization degree and size of the honey crystals. Moreover, observations conducted with a microscope (Delta Optical) at 10x magnification allowed the size, amount and distribution of glucose crystals to be determined.

The honey was analyzed in accordance with the regulation for honey quality assessment analysis (RMRiW Journal of Laws of 2015, item 
1773, as amended) and included refractometric determination of water content (RHN1-ATC, refraktometr.eu, Czech Republic), acidity using a $\mathrm{pH}$ meter (Elmetron, CP-461) and a diastase number by the spectrophotometric method (Biomate 3, Thermo, USA) using the Phadebas Honey Diastase Test ('Magle AB Lund, Sweden 2010) according to the manufacturer instructions.

As an additional sensitive indicator, the activity of three selected glycolytic enzymes: $a$-glucosidase (a-GLU), $\beta$-galactosidase ( $\beta-G A L)$ and $\alpha$-mannosidase (a-MAN) were determined spectrophotometrically with the use of appropriate synthetic p-nitrophenol substrates. For determination, a $20 \% \mathrm{w} / \mathrm{v}$ aqueous honey solution was used. The reaction mixture contained $25 \mu$ of substrate in $0.2 \mathrm{M}$ citric buffer (for $\beta$-GAL pH 4.0; a-GLU pH 5.5 and a-MAN pH 5.0) and $25 \mu$ of sample introduced into a well of a microplate. The control sample contained the sample and appropriate buffer instead of substrate. Samples were incubated at $37^{\circ} \mathrm{C}$ for sixty minutes. After this time, the reaction was stopped by the addition of $250 \mu \mathrm{l} 1 \mathrm{M}$ carbonate buffer $(\mathrm{pH} \mathrm{10})$ and absorbance was measured at $405 \mathrm{~nm}$ with an Elisa microplate reader (Clindiag, Belgium). Each determination was done in triplicate. Enzyme activity was expressed in units per $\mathrm{g}$ of honey [U/g]. Diastase activity was determined with Phadebas ${ }^{\oplus}$ Honey Diastase Test strictly according to manufacturer instruction.

Antioxidant activity was determined based on the ability to neutralize DPPH (free radical scavenging activity) with $20 \%$ honey solution. A solution of DPPH was added to the sample, and after thirty minutes the absorbance $(A)$ was measured at a wavelength $\lambda=517 \mathrm{~nm}$ relative to the control $(\mathrm{Ao})$. The percentage inhibition [\%] of DPPH was calculated from the equation: $[\% A]=($ Ao $-A) / A o \times 100 \%$ (Dżugan et al., 2018). Total phenolics content (TPC) was determined on the basis of the colored reaction of polyphenols with the Folin-Ciocalteu reagent, and the absorbance of the resulting complex was measured at a wavelength $\lambda=760 \mathrm{~nm}$. The total content of polyphenols was expressed as mg of gallic acid equivalent per $\mathrm{kg}$ of honey (GAE), for which a calibration curve was made in the concentration range of $0 \div 100 \mathrm{mg}$ GAE/kg (Dżugan et al., 2018).

The 5-hydroxymethylfurfural (HMF) concentration was determined colorimetrically at $550 \mathrm{~nm}$ as a result of the reaction of HMF with barbituric acid and p-toluidine in an acid medium where a red product is formed. The result was calculated from the formula: HMF $=19.2 \times(A / d) \times 10$, with 19.2- conversion factor, $d$ - fluid thickness in the cuvette and A- mean of the absorbance. Results were expressed as mg of HMF per kg of honey. All tests were performed in triplicate. The results are expressed as mean values with standard deviations (SD). The differences between individual groups were analyzed with the use of the one-way analysis of variance with Tukey's test, $p<0.05$ significant statistical differences were accepted. The Statistica 13.1 program was used for the calculations.

\section{RESULTS}

Visual observations showed that fresh honey subjected to microwave radiation and ultrasound fixation ( $1^{\text {st }}$ treatment) crystallized more slowly in comparison to the control honey, and the rate of transformation of liquid honey into crust varied depending on the honey variety (Tab. 1). Control samples of all honey varieties were found to naturally crystallize after twelve months of storage at room temperature, whereas in samples fixed with microwave and ultrasounds the delay of crystallization process was observed. The samples fixed with ultrasounds solidified more slowly as compared to other samples. The only exception was lime honey, while the prolongation of the sonication time did not affect the crystallization process significantly.

The fixation influenced not only the rate of the crystallization process but also changed the form of crystallized honey. During microscopic studies we compared the degree of crystallization and the crystal structure of the treated honeys in relation to the control sample in terms of size, shape, amount and distribution of crystals. The formation of large crystals was observed in the 


\section{— SIDOR ET fhl. _ Ultrasounds in honey fixation or decrystallization}

Table 1.

Impact of $1^{\text {st }}$ treatment on the crystallization rate of honey during twelve months of storage

\begin{tabular}{ccccc}
\hline Variety & Control (C) & Microwave (M) & $\begin{array}{c}\text { Ultrasounds } 5 \text { min } \\
\text { (U5) }\end{array}$ & $\begin{array}{c}\text { Ultrasounds 20 min } \\
\text { (U20) }\end{array}$ \\
\hline Acacia & $\begin{array}{c}\text { Semisolid, crystals } \\
\text { throughout the } \\
\text { sample }\end{array}$ & $\begin{array}{c}\text { Liquid with crys- } \\
\text { tallization process } \\
\text { started }\end{array}$ & Liquid, fine crystals & $\begin{array}{c}\text { Liquid with crystalliza- } \\
\text { tion process started }\end{array}$ \\
Multi- & $\begin{array}{c}\text { Total crystallization } \\
\text { with clusters of } \\
\text { floral } \\
\text { coarse crystals }\end{array}$ & $\begin{array}{c}\text { Visible few clusters } \\
\text { of coarse crystals }\end{array}$ & All liquid volume & $\begin{array}{c}\text { Advanced crystalliza- } \\
\text { tion process, coarse } \\
\text { crystals }\end{array}$ \\
Lime & Solid, thick crystals & $\begin{array}{c}\text { Liquid with thick } \\
\text { crystals }\end{array}$ & $\begin{array}{c}\text { Solid with thick } \\
\text { crystals suspended } \\
\text { in the whole } \\
\text { sample }\end{array}$ & $\begin{array}{c}\text { Completely crystal- } \\
\text { lized, fine-grained } \\
\text { crystals }\end{array}$ \\
\hline
\end{tabular}

microwave-fixed honey, while smaller crystal According to the literature, lime honey crystalsizes were observed in the honey fixed with lizes within a few to several weeks, multifloral ultrasounds in comparison to the control honey honey within a few months, while acacia honey (natural crystallization) (Fig. 1).

needs a dozen or so months (Bogdanov, 2011).

The obtained results indicate that the crys- Microscopic examination of naturally crystallized tallization process was performed correctly. varietal honeys showed that lime honey crystal-
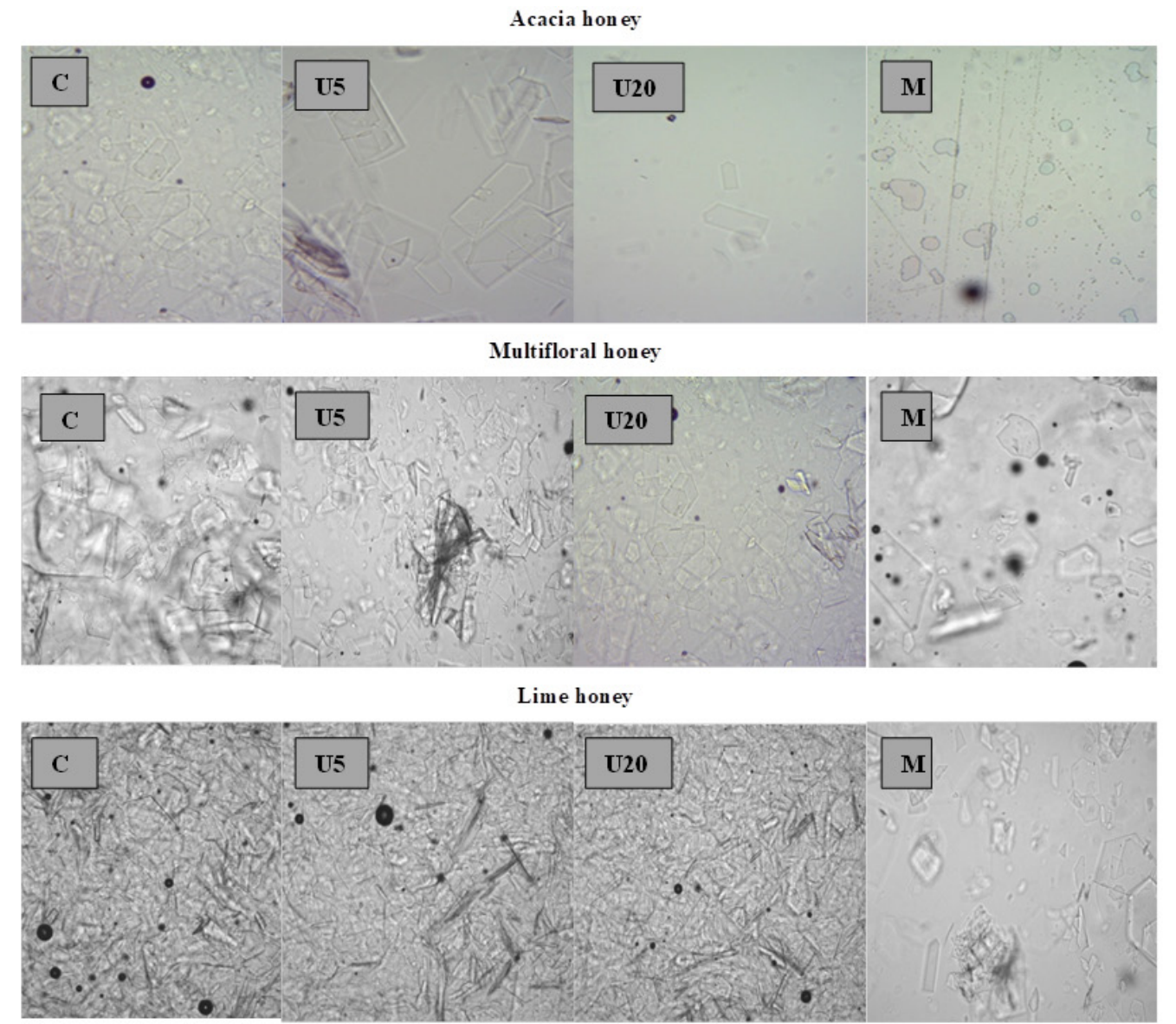

Fig. 1. Crystal structure of acacia, multifloral and lime honey stored for 12 months: naturally crystallized (control-C), after $1^{\text {st }}$ treatment (fixation) with ultrasounds in shorter (U5) or longer (U20) time and with microwaves (M). 
lized the fastest. There are very large clusters of glucose that prevent the identification of a single molecule. Only the use of microwaves significantly slowed down the crystallization of honey. The fixation had the greatest impact on the structure of acacia honey. The use of both, microwaves and U20 caused a visible slowdown in the crystallization process. The microscopic observation showed few visible glucose particles only.

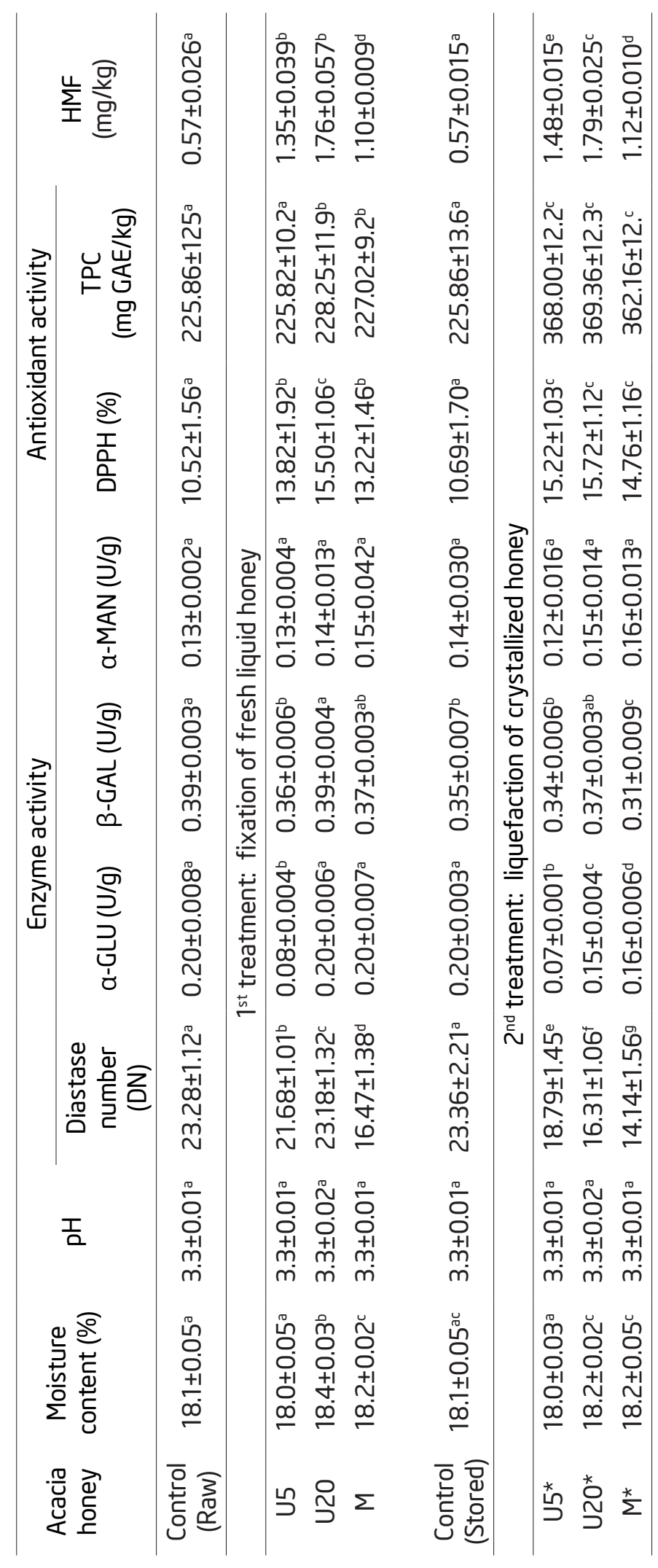

Table 2.

Physicochemical analysis of fresh acacia honey, after fixation ( $1^{\text {st }}$ treatment) with ultrasounds (U5 and U20) and microwaves $(M)$ in order to delay crystallization and liquefaction ( $2^{\text {nd }}$ treatment) with the same methods (U5*, U2O* and $M *$ ) after 12 months of storage in laboratory conditions at room temperature in the dark. The results were presented as mean value $\pm S D(n=3)$ a,b,c,d,e,f,g - means marked with different letters within the column differ statistically $(P<0.05)$ 
All samples stored by twelve months were subjected to the $2^{\text {nd }}$ treatment with the use of ultrasounds and microwaves until honey was obtained in liquid form, with no crystals visible

Table 3.

Physicochemical analysis of fresh multifloral honey, after fixation (1 ${ }^{\text {st }}$ treatment) with ultrasounds (U5 and U20) and microwaves (M) in order to delay crystallization and liquefaction ( $2^{\text {nd }}$ treatment) with the same methods (U5*, U20* and $M *$ ) after 12 months of storage in laboratory conditions at room temperature in the dark. The results were presented as mean value $\pm S D(n=3)$ $a, b, c, d, e, f, g$ - means marked with different letters within the column differ statistically $(P<0.05)$ 
under the microscope. The time for full liquefaction by ultrasonics treatment was shorter for lime (25 min) than for other honey varieties, whereas with the use of microwaves the time

Table 4.

Physicochemical analysis of fresh lime honey, after fixation (1 ${ }^{\text {st }}$ treatment) with ultrasounds (U5 and U20) and microwaves (M) in order to delay crystallization and liquefaction ( $2^{\text {nd }}$ treatment) with the same methods (U5*, $U 20^{*}$ and $M *$ ) after 12 months of storage in laboratory conditions at room temperature in the dark. The results were presented as mean value $\pm \operatorname{SD}(n=3)$ a,b,c,d,e,f,g - means marked with different letters within the column differ statistically $(P<0.05)$ 
needed for acacia decrystallization was by 2-fold shorter. The liquid samples were evaluated according to water content, $\mathrm{pH}$ and HMF content, 4 glycolytic enzyme activities and antioxidant activity. The results were presented separately for each honey variety: acacia (Tab. 2), multifloral (Tab. 3) and lime (Tab. 4). During twelve months of storage at room conditions, no significant changes in terms of tested parameters for control samples were observed regardless of honey variety (Tab. 2-4). Meanwhile, both used processing slightly disturbed honey properties excluding HMF content and $\beta$-galactosidase activity.

The applied treatments significantly influenced the water content in honeys $(P<0.05)$. The analysis of fresh honey $\mathrm{pH}$ showed the values in the following order: lime> multifloral> acacia honeys. Both the fixation and liquefaction process of acacia honey did not affect its $\mathrm{pH}$ $(P>0.05)$ (Tab. 2), and a statistically significant $(\mathrm{P}<0.05)$ increase in $\mathrm{pH}$ was observed during the $1^{\text {st }}$ treatment of multifloral honey only with the use of all methods (Tab. 3). In the case of lime honey (Tab. 4), significant changes in $\mathrm{pH}$ were observed for samples subjected to the liquefaction process with all the methods used. The tested fresh honeys showed $\mathrm{pH}$ in the range of 3.3-3.8. The value of the diastase number (DN) was variety-dependent, the highest for fresh multifloral (26.01 DN) and the lowest for acacia (23.28 DN) honeys were observed (Tab. 2 , 4). During fixation, the microwave method caused the largest DN losses. For microwavefixed samples, the loss of diastase activity as compared to the control sample amounted from $12 \%$ to $30 \%$ for lime and acacia honey, respectively. The $2^{\text {nd }}$ treatment (liquefaction) by microwave ( $M^{*}$ sample) caused a further decrease in diastase activity, from $9 \%$ for lime honey to $31 \%$ for multifloral honey. Compared to the control sample, the use of the microwave decrystallization method as well as ultrasound for five minutes had the greatest impact on the reducing of diastase number even prolonged ultrasonics processing.

Diastase is the main enzyme studied in honey and is used as a quality standard to control honey overheating. Other honey glycosidases, including a-glucosidase, $\beta$-galactosidase, and a-mannosidase, are not widely analyzed (Elezau et al., 2013). The studies showed that in all of the tested honeys, the glycosidase activity decreases in sequence: $\beta-G A L>a-G L U>a-M A N$ (Tab. 2-4). The highest activity of these enzymes was observed in lime, next in multifloral and then in acacia honey. A reduced activity of the tested enzymes was found in honeys that were fixed, regardless of the technique used, the strongest in multifloral honey fixed with the U5 method (69\%). Smaller changes were observed for honey fixed and then liquefied using microwave method (17\%). The liquefying of honeys resulted in a further reduction of enzyme activity in the tested samples. The $2^{\text {nd }}$ treatment of honey caused a significant decrease in the activity of the a-glucosidase enzyme in lime honey (73\%), while the smallest decrease in the activity of the a-mannosidase enzyme (2-10\%) was observed in all honey varieties (Tab. 2-4).

The tested fresh honey showed the ability to scavenge free radicals in the range of $10-31 \%$ (Tab. 2-4), with the highest antioxidant activity characterized by lime honey (Tab. 4) and the lowest by acacia honey (Tab. 2). At the final stage of experiments, significant increases in the antioxidant activity in acacia and multifloral honey were found (Tab. 2-3). The greatest changes in antioxidant activity after the $2^{\text {nd }}$ treatment process was demonstrated in the U20* acacia honey sample (increase by $49 \%$ ). The process of liquefaction of multifloral honey increased the antioxidant activity, the highest of which was in the sample $M^{*}(20 \%)$ and U20* $(12.8 \%)$ (Tab. 3). Both fixation and liquefaction significantly influenced the antioxidant properties of lime and acacia honeys (Tab. 2, 4).

The total content of polyphenols in fresh honeys was in the range of 225-659 mg GAE/ $\mathrm{kg}$ of honey, with the highest level in lime honey (Tab. 4) and the lowest in acacia honey (Tab. 2). Depending on the method (U5, U20 and M) used in the $1^{\text {st }}$ treatment of honey, statistically significant changes were observed in the total content of phenolic compounds $(p<0.05)$ compared to the control honey. The highest 
increase was recorded in lime honey sonicated for $5 \mathrm{~min}$ ( $5 \%$ compared to the control sample) (Tab. 4), while the highest statistically significant decrease was recorded in multifloral honey fixed with the $M$ method (8.4\%).

Under the influence of elevated temperature and long storage, honey may undergo a non-enzymatic browning process that occurs between reducing sugars and amino acids, peptides or proteins containing a free amino group. This creates compounds with health-promoting properties, phenolic compounds, but also unwanted HMF. The highest HMF values were found in fresh multiflorous honey $(0.67 \mathrm{mg} / \mathrm{kg})$, and the lowest in lime honey $(0.08 \mathrm{mg} / \mathrm{kg}$ ) (Tab. 2-4). The process of honey fixation resulted in a significant increase in the HMF content in the tested samples. However, the HMF content was still below the established EU limits (below $40 \mathrm{mg} / \mathrm{kg}$ ). The U20 method resulted in the highest increases in HMF levels and the lowest microwave binding, which was probably due to the processing time. This relationship was found for all types of fixed and liquefied honeys.

\section{DISCUSSION}

In terms of water content, all the tested honeys (Tab. 2-4), fresh, stored and processed, met the requirements set out in the applicable legal provisions (below 20\%) (RMRiW Journal of Laws of 2015, Item 1173, as amended). The results obtained for fresh honeys were comparable with the results obtained by other authors for Polish (Wilczyńska, 2011; Dżugan et al., 2017) and European (Laos et al., 2011; Shelear, 2013; Tomczyk et al., 2019) honeys. Shelear (2013) who conducted research on the impact of the storage on the quality of honey, showed a similar results of DN (in the range of 16.2-17.9) for fresh honey and decrease in a-amylase activity during storage by $19.45-79.85 \%$ depending on the variety of honey. These results obtained for diastase number are also comparable with the data presented by Skowronek et al. (1994). In addition, Wesołowska \& Dżugan (2017) noted a significant decrease in diastase activity (from 17 to $42 \%$ ) depending on the type of honey during long-term storage of samples at a temperature of $20 \pm 2^{\circ} \mathrm{C}$ for 24 months. However, despite the observed losses, the DN values found in fixed or liquefying honeys were still within the standard requirements, mainly due to the high diastase activity of fresh Polish honey (Wilczyńska et al., 2010; Dżugan et al., 2017; Wesołowska \& Dżugan, 2017; Tomczyk et al., 2019).

The results obtained for antioxidant activity for fresh honey were in agreement with earlier studies (Wilczyńska, 2011; Dżugan et al., 2018) where the antioxidant activity for various varieties of fresh honey as $25-43 \%$ on average was reported. The obtained results also confirm the relationship found by Kaškoniene et al. (2009), that light honeys contain significantly less polyphenols than dark honeys as well as the findings of Żak et al. (2017) who showed a content of polyphenols in the range of 112-760 $\mathrm{mg} / \mathrm{kg}$. In our experiment, honey processing and/or storage resulted in an average of 62\% increase in antioxidant properties. Similarly, Wilczyńska (2010) found an increase in the content of phenolic compounds during honey storage. The above results may indicate that non-enzymatic browning reactions occur during storage and/or thermal processing. The honey darkening processes are related to the formation of melanoidins, products of the Maillard reaction with antioxidant properties, which compensate the loss of other natural ingredients.

White (1979) analyzed 40 fresh honey samples and showed a HMF content up to $4.83 \mathrm{mg} / \mathrm{kg}$, which was similar to our fresh or processed honeys. Shelear (2013) found for thermally decrystallized honeys an increased HMF level in all tested samples depending on the processing temperature and storage duration. Based on the experiment, it can be concluded that the use of ultrasound and microwave for honey decrystallization is fast and safe regarding HMF formation.

A few studies have been related to the use of ultrasounds to honey processing but the use of microwave has been less frequent (Thrasyvoulou et al., 1994; Bakier, 2007; Stasiak \& Dolatowski, 2007; Kowalski et al., 2012; Subramanian et al., 2017). However, all of these 
authors focused on the physical aspects of decrystallization process and honey quality parameters according to legal requirements, including diastase activity. Our study deepens the knowledge about the effect of honey processing with ultrasounds or microwaves in terms of the more sensitive indicators of honey bioactivity which can be directly related to its antibacterial activity (Dżugan et al., 2018). The study based on antioxidant activity, polyphenolic content and activity of selected glycosidases, rarely studied in honey, confirmed the benefits of the use of ultrasonics processing to honey liquefying. Moreover, the process of the crystallization of fresh honey may be delayed by the use of ultrasonic waves, with slight changes in the biological properties of honey.

In conclusion, the use of ultrasounds for honey decrystallization allows for a significant shortening of the liquefaction process and for maintaining the quality of honey required by relevant legal regulations. The use of microwaves was also effective but the greater changes in enzymatic activity were observed due to the stronger overheating of honey. Our new tested idea is soft fixation of fresh honey with ultrasounds which delay the crystallization process during shelf-life which would be of great importance for consumers who prefer liquid honey. During honey liquefaction, the observed disturbances in studied parameters were lower than reported during the use of conventional thermal heating method whereas the time of processing was significantly shortened. However, because this is the first research focusing on the use of additional parameters to assess honey behavior during ultrasonics processing, it needs further studies.

\section{REFERENCES}

Abeshu, M.A., \& Bekesho, G. (2016). Medicinal use of honey. Biology and Medicine, 8(2), 279. DOl: 10.4172/0974-8369.1000279

Bakier, S. (2007). Honey liquefaction methods. Postępy Techniki Przetwórstwa Spożywczego, 1, 32-35.
Bakier, S., \& Pękala, L. (2007). Charakterystyka konstrukcji i efektów upłynniania miodu w urządzeniu D1. Inżynieria Rolnicza. 5(93), 23-29.

Bogdanov S. (2011) Honey Technology. In: The Book of Honey. Bee Product Science, http://www.beehexagon.net/

Bhandari, B., D'Arcy, B., Kelly, C. (2009). Rheology and crystallization kinetics of honey: Present Status. International Journal of Food Properties, 2(3), 217226.

Borkowska, J., Bednarski, W., Gołębiewska, J. (2011). Charakterystyka sacharydów miodu oraz możliwości zastosowania Bifidobacterium do modyfikacji ich składu i właściwości. Żywność. Nauka. Technologia. Jakość, 3(76), 29-39.

Dżugan, M. Wesołowska, M., Sowa, P., Swacha, S., Zaguła, G. Zgłoszenie patentowe: „Sposób skrócenia czasu upłynnienia i opóźnienia krystalizacji miodu” P. 420598 z dn. 20.02.2017 г.

Dżugan, M., Tomczyk, M., Sowa, P., Grabek-Lejko, D. (2018). Antioxidant activity as biomarker of honey variety. Molecules, 23(8), 2069. DOl: 10.3390/ molecules23082069

Eleazu, C.O., Iroaganachi, M.A., Eleazu, K.C., Okoronkwo, J.0. (2013). Determination of the physico-chemical composition, microbial quality and free radical scavenging activites of some commercially sold honey samples in Albania, Nigeria: The Effect of Varying Colors. Journal of Nutition \& Food Sciences, 3(2), 32-41. DOI: 10.7439/IJBR.V4I1.910

Kaškoniene, V., Maruška, A., Kornyšova, O. (2009). Quantitative and qualitative determination of phenolic compounds in honey. Chemine Technologija, 3(52), 74-80.

Kowalski, S., Lukasiewicz, M., Bednarz, S., Panus, M. (2012). Diastase number changes during thermal and microwave processing of honey. Czech Journal of Food Sciences, 30(1), 21-26. https://doi. org/10.17221/123/2010-CJF. 
Laos, L., Kris, E., Pall, R., Martverk, K. (2011). The crystallization behavior of Estonian honeys. Agronomy Research, 9(2), 427-432.

Rozporządzenie Ministra Rolnictwa i Rozwoju Wsi z dnia 30 lipca 2015 r. w sprawie metod analiz związanych z dokonywaniem oceny miodu. Dz.U. 2015. Nr 17, poz. 94

Rybak-Chmielewska, H., Szczęsna, T., Waś, $E_{. \prime}$ Jaśkiewicz, K., Teper, D. (2013). Characteristics of polish unifloral honey IV. Honeydew honey, mainly Abies alba L. Journal of Apicultural Science, 571), 5158. DOl: 10.2478/jas-2013-0006

Shapla, U.M., Solayman, Md., Alam, N., Khalil, Md.I., Gan, S.H. (2018). 5- hydroxymethylofurfural (HMF) levels in honey and other food products: effects on bees and human health. Chemistry Central Journal, 12(35), 1-18. DOI: 10.1186/s13065-018-0408-3

Shelear, H.H. (2013). Effect of Storage and processing temperatures on honey quality. Pure and Applied Sciences, 6(21), 2244-2253.

Skowronek, W., Rybak-Chmielewska, H., Szczęsna, T., Pidek, A. (1994). Wpływ czynników opóźniających krystalizację miodu na jego jakość. Pszczelnicze Zeszyty Naukowe, 44, 23-32.

Sohaimy, S.A. El., Masry, S.H.D., Shehata, M.G. (2015). Physicochemical characteristics of honey from different origins. Annals of Agricultural Science, 60(2), 279-287. https://doi.org/10.1016/j. aoas.2015.10.015

Stasiak, D.M., \& Dolatowski, Z.J. (2007). Effect of sonication on the crystallization of honeys. Polish Journal of Food and Nutrition Sciences, 57,3(A), 133136.

Subramanian, R., Hebbar, U.H., Rastogi. N.K. (2017). Processing of honey: A review. International Journal of Food Properties, 191), 127-143. https://doi. org/10.1080/10942910600981708
Thrasyvoulou, A., Manikis, J., Tselios, D. (1994). Liquefying crystallized honey with ultrasound waves. Apidologie, 25(3), 297-302. DOl: 10.1051/ apido:19940304

Tomczyk, M., Tarapatskyy, M., Dżugan, M. (2019). The influence of geographical origin on honey composition studied by Polish and Slovak honey. Czech Journal of Food Sciences, 37,232-238. https:/l doi.org/10.17221/40/2019-CJFS

Wesołowska, M., \& Dżugan, M. (2017). Activity and thermal stability of diastase occurring in Podkarpackie varietal honeys. Żywność. Nauka. Technologia. Jakość, 24(113), 103-112. DOl: 10.15193/ zntj/2017/113/214

White, J.W. Jr. (1979). Spectrophotometric method for hydroxymethylofurfural in honey. Association of Official Analytical Chemists, 62(3), 509-514.

Wilczyńska, A. (2010). Phenolic content and antioxidant activity of different types of Polish honey - a short report. Polish Jouranl of Food and Nutrition Sciences, 60(4), 309-313.

Wilczyńska, A. (2011). Zmiany barwy oraz aktywności antyoksydacyjnej miodów podczas przechowywania. Bromatologia. Chemia. Toksykologia, 44(3), 945-950.

Żak, N., Wilczyńska, A, Przybyłowski, P. (2017). Jakość miodów zagranicznych w odniesieniu do polskich standardów - badania wstępne. Problemy Higieny $i$ Epidemiologii, 98(3), 245-249. 